\title{
Gratitude On Working Mother And Not- Working Mother
}

\author{
Nancy Naomi G.P. Aritonang \\ Department of Psychology University of HKBP Nommensen \\ omie80_art@yahoo.com
}

\begin{abstract}
The aim of this study was to determine wheter working mothers and not-working mothers differ with regard to aspects of gratitude. Gratitude is an expression of admiration, thankful, and appreciation of something belong to. This expressions are intended to others, human being or some entities like God (Emmons \& Shelton, 2002).For the purpose of this study, a meta-analysis was performed on data from reseach involving availability sample of 64 , in range of 25 to 50 years old working mothers and not-working mothers. The participants each complete GQ-6 scales that measure gratitude in a warm sense of appreciation, a sense of goodwill, and a disposition to act aspects. The data analyzed quantitavely using t-test and statistically working status difference were not found, thus the hypothesis is rejected. There is no significant difference gratitude between working mothers and not-working mothers, with value of $\mathrm{p}=0.668(\mathrm{p}>0.05)$, and the value of $\mathrm{t}$ sum $=1.983<$ $\mathrm{t}$ table $=1.998$. The statistically result shows that $90.6 \%$ working mothers have gratitude in high level, and $87.5 \%$ not-working mothers also have gratitude in high level. So, the conclusion of this study is gratitude of working mothers and not-working mothers has no difference.
\end{abstract}

Keywords: pastor, needs, personality.

\section{Introduction}

The phenomenon of working mothers has been discussed many times in the era of modern society today. Working mothers are women who are married and have responsibilities as wives or mothers of their children while working outside the home as a career woman (Sigelman, 1994) and have a double role (double burdon), namely as a career woman (productive duty), giving birth and educating children (reproductive tasks), household managers while at the same time playing a social role in the family (Harjoni, in Sastriyani, 2005).

Tan (1991) states that there are two attitudes in society in seeing the right role for Indonesian women. On the one hand, culturally women act as good wives, mothers and household managers. On the other hand, women are 
a source of human labor that has the same position as men so they are also entitled to work. However, the majority of Indonesian society still adheres to paternalisticism, where the structure of society is generally still patriarchal and the main institution of this system is the family. This domination occurs because the economic position of women is weaker than men (Budiman, 1985: 60 in Sudarwati, 2003) so that women in meeting their material needs are very dependent on men. Husband status and role are generally more dominant than wife. The role of men (husbands) as the head of household and women's (wives) role as a housewives. Although women are also allowed to work, domestic responsibilities remain on their shoulders. This is why although working together, women are more prone to work-family conflict compared to men.

According to Santrock (2002) the role played by working mothers could cause of stress by the demands of additional time and energy, the division of time for family and career, the conflict between work roles and family roles, competitive competition between husband and wife, as well as the problem important is whether attention to the needs of children has been fullfiled or not. Lubis (2013) also revealed that working mothers tend to influence family harmony. That is because the busyness of excessive activity tends to make a mother do not have much time for the family and the mother's focus of attention that is more directed to career success can make a mother to abandon her role as a wife and also as a mother.

Working mothers are often assumed to have feelings of guilt for not having sufficient time with children, but a study shows different results. Research conducted by APA (2011) shows that working mothers are happier and healthier than mothers who do not work, especially those who have children from infancy to preschool age. Recent research from the Parenting Mumsnet website (in Febrida, 2014) conducted on 900 mothers shows that nearly half that as much as $48 \%$ of subjects say having paid work makes mothers happier. As many as $52 \%$ of subjects said staying at home was more difficult than going to work. Only $13 \%$ of working mothers feel guilty about spending their time away from home. This is because working mothers who have limited time will have more energy when the time with their children.

Other studies show the same results based on research conducted to 60,799 women showing that mothers who do not working or as housewives only, experience more negative emotions such as worry, sadness, anger, stress, and depression, compared to working mothers. This study shows $41 \%$ of housewives experience anxiety, while only $34 \%$ of working mothers experience similar feelings. Stress also occurs in $50 \%$ of housewives, and $48 \%$ 
of working mothers. Anger was found in $19 \%$ of housewives and $14 \%$ of working mothers.

The above phenomenon shows that generally being a mother who does not work is more likely to have a variety of negative emotions, such as feeling anxious, angry, sad, stressed and even depressed than a mother who is not working.

Choosing to be a housewife and working mother will have advantages and disadvantages that must be faced by women. The advantage of being a housewife is that mothers can have more time for their family and do not feel stress due to role conflict, while the shortcomings experienced by housewives are a higher tendency to deal with negative emotions such as worry, sadness, anger, stress, and depression compared to working mothers. The strengths of working mothers are being more independent, equal relationships with their husbands, and also increasing self-esteem, while the disadvantage is that working mothers have a tendency to have role conflicts. The difference in strengths and weaknesses that are carried out by both women who act as housewives and working mothers will have an impact on psychological wellbeing that has been achieved by mothers (Apsaryanthi \& Lestari, 2017).

Gratitude is an expression form of happiness related to well-being. Gratitude activities can maintain a person's psychological well-being (Hefferon \& Boniwell, 2013, in Kristianto, 2016). Grateful for all things can be done by everyone through positive words, praise, sweet words that come out of someone's mouth, cheerful laughter, singing, also as a sign of happiness. This is very easily done by anyone who is grateful in a pleasant heart condition (good mood) (Schwart \& Clore, 1983, in Sirgy, 2012).

Gratitude is a kind of expression of admiration, grateful, and appreciation for something that is owned. The phrase can be addressed to other parties, both to fellow human beings and certain entities such as God. (Emmons \& Shelton, 2002). Gratitude in life can lead to thoughts of peace, happiness, physical health, and deeper, more fulfilling personal relationships (Snyder \& Lopez, 2012). A focus on gratitude can make life more complete, meaningful and productive (Emmons \& Crumpler, 2000). Gratitude can also make someone better and wiser, can create harmony between himself and the environment and community.

According to McCullough, Emmons \& Tsang (2004) there are 3 factors that contribute to one's gratitude: 1) Emotionality Well-being, is the tendency or extent to which a person reacts emotionally and feels satisfaction in his life, 2) Prosociality is one's tendency to be accepted by social environment, 3) Spirituality, which is related to religion, faith which involves transcendental related vertical relationship with God. Religious values make executors have 
high hopes and optimism. One's understanding of religious values influences the extent to which a person is able to give thanks (Van Cappelen \& Rime, 2014).Furthermore, McCullough, Emmons \& Tsang (2004) explain that gratitude consists of four interdependent aspects. First, individuals with a level of gratitude tend to experience gratitude more frequently (frequency), second, gratitude experience (intensity) significantly influences the emergence of behavior, individuals are more sensitive to life experiences that arouse gratitude (range), fourth, more and more sincere recognition of individuals who might have contributed to their personal achievements (density).

There are three important components in gratitude, that is: 1) a warm sense of appreciation, is a positive assessment and appreciation of someone or something, including feelings of love, and affection, 2) a sense of goodwill, is a good will (goodwill) that addressed to someone or something, including the desire to help others in distress, the desire to share, etc., 3) a disposition to act, is a tendency to act positively in order to give appreciation and good will to others for what is obtained, the environment and God, includes the intention to help others, and do some kindness to others. The roles difference between working and not-working mothers influences their psychological well-being. Apsaryanthi \& Lestari (2017) research on working mothers and housewives in Gianyar Regency found that there were significant differences in psychological well-being between working mothers and housewives. This is consistent with statements from Betz, Cleveland, Rogers and DeBoer (in Matlin, 2012) that work owned by women can increase self-esteem. Many working women report higher feelings of competence, achievement and life satisfaction than women who do not work. This is also supported by research conducted by Susanti, 2012 (in Apsaryanthi \& Lestari, 2017), that the higher self-esteem means the higher the psychological well-being in working women. In other studies show that grateful activities make someone feel happy, optimistic and feel life satisfaction (Emmons, 2007, in Kristianto, 2016). Gratitude is a behavioral concept that underlies a variety of positive psychological interventions and has undeniable relevance to life's well-being and satisfaction. Gratitude is considered a psychological power that plays an important role in minimizing negative feelings in a person. Based on the above problem formulation, the purpose of this study is as follows: To find out the difference in gratitude (gratitude) between working mothers and mothers who do not work. 


\section{Significance of the study}

The hypotheses proposed in this study are: Woman. This will help women, both working and not-working mothers, in order to develop ways of increasing gratitude and improve their psychological well-being. Other researchers. This will enrich the science of psychology, especially in the field of Industrial and Organizational Psychology about differences in gratitude) for working mothers and not-working mothers.

\section{Scope and Limitation of the study}

The scope area of study is urban area residence in Medan City, Indonesia. The study is conducted on sampling of household survey. Limitation is only research the household in urban residence area (centre or middle city), not including the rural residence area (suburbs). The assumption is that there is a difference in gratitude among working mothers and not-working mothers, especially to mothers who lives in urban area.

\section{Setting of the study}

This study took place at some residences and school in urban area of Medan City, during March - April of 2018.

\section{RESEARCH DESIGN AND METHODOLOGY}

The method used in this study is a quantitative research method. The variable used is Gratitude as the dependent variable. Gratitude is is an expression of gratitude or self-acceptance response to what is obtained, which can lead to thoughts of peace, happiness, physical health, and a more satisfying personal relationship.

\section{Respondents of the study}

The population in this study are working mothers and not-working mothers (housewives) who have children under five.

\section{Sampling Procedure}

The sampling technique used in this study is a simple random technique, which is a sampling technique was carried out by randomly taking 32 working mothers and 32 notworking mothers (housewives). Data collection methods in this study, using Likert Scale with five (5) response format choices 
that move from the answer choices STS (Strongly Disagree), TS (Disagree), N (Neutral), S (Agree), SS (Strongly Agree).

\section{Research Instrument}

The data collection instruments used in this study is GQ-6 Gratitude Scale Instrument. The scale compiled by McCullough, Emmons \& Tsang reveals about: 1) A warm of sense of appreciation, 2. Sense of Goodwill, 3. A Disposition to Act. Here is a blueprint of the GQ-6 Gratitude scale:

Tabel 2. Blue Print Gratitude

\begin{tabular}{|l|l|c|c|c|}
\hline \multirow{2}{*}{ No } & \multicolumn{1}{|c|}{ Aspects } & \multicolumn{2}{|c|}{ Item } & Total \\
\cline { 3 - 5 } & & Favourable & Unfavourable & \\
\hline 1 & $\begin{array}{l}\text { a warm sense of } \\
\text { appreciation }\end{array}$ & 1,4 & 3 & $\mathbf{3}$ \\
\hline 2 & a sense of goodwill & 5 & - & $\mathbf{1}$ \\
\hline 3 & a disposition of act & 2 & 6 & $\mathbf{1}$ \\
\hline & Total & $\mathbf{4}$ & $\mathbf{2}$ & $\mathbf{6}$ \\
\hline
\end{tabular}

\section{Data Gathering Procedure}

\section{Statistical Analysis}

Data analysis is performed to test the hypothesis in order to draw conclusions to achieve the research objectives. According to Hadi (2000), data analysis is a way for researchers to process collected data so that they get a conclusion from their research. Data analysis in this research was carried out by testing assumptions and hypothesis testing. The classic assumption test used in this study consists of a normality test, and the hypothesis test used is the Independent t-test. Both tests were carried out using SPSS 17 software.

\section{FINDINGS AND CONCLUSIONS}

After the data from the research scale are collected, data analysis is performed which includes descriptive analysis and independent t-test analysis. Descriptive analysis includes a comparison between hypothetical mean and empirical mean. The hypothetical mean for expressing gratitude (gratitude) in this study was 24.5 The empiric mean of gratitude for working mothers in this study was 36.38 , and the empirical mean or gratitude for not-working mothers 
was 34.34. After comparing the hypothetical mean with the empirical mean, the results of descriptive data are obtained that the empirical mean of the gratitude was 36.36, above the hypothetical mean was 24.5. This shows the average subject was in the high category.

\section{a. Based on Gratitude Level}

Table 1. Data Categorization of Gratitude Level

\begin{tabular}{|l|c|c|c|c|c|c|}
\hline \multirow{2}{*}{ Gratitude } & \multicolumn{6}{c|}{ Categorization } \\
\cline { 2 - 7 } & \multicolumn{2}{|c|}{ Low } & \multicolumn{2}{c|}{ Medium } & \multicolumn{2}{c|}{ High } \\
\cline { 2 - 7 } & Total & $\%$ & Total & $\%$ & Total & $\%$ \\
\hline Working mothers & 0 & 0 & 3 & 9.4 & 29 & 90.6 \\
\hline $\begin{array}{l}\text { Non-working } \\
\text { mothers }\end{array}$ & 0 & 0 & 4 & 12.5 & 28 & 87.5 \\
\hline
\end{tabular}

The descriptive test showed that there were 3 working mothers with moderate gratitude in the medium category (9.4\%), and the high category was 29 people (90.6\%). While the gratitude for not-working mothers is in the medium category were 4 people $(12.5 \%)$, and the high category were 28 people $(87.5 \%)$.

\section{b. Based on Age of mothers}

Table 2. Data Categorization of subject age (years)

\begin{tabular}{|c|c|c|}
\hline \multirow{2}{*}{ Age ( years) } & \multicolumn{2}{|c|}{ Total Subjects } \\
\cline { 2 - 3 } & Working mothers & Not-working mothers \\
\hline $25-30$ & 3 & 1 \\
\hline $31-35$ & 11 & 8 \\
\hline $36-40$ & 12 & 13 \\
\hline $41-45$ & 6 & 8 \\
\hline $46-50$ & 0 & 2 \\
\hline Total & 32 & 32 \\
\hline
\end{tabular}

The number of working mothers who are in the age range of 25-30 years amounted to 3 people, the age range of 31-35 years were 11 people, the age range of 36-40 years were 12 people, the age range of 41-45 years were 6 people, the age range of 46- 50 years were no people. While the number of not-working mothers who has age range of 25-30 years was 1 person, the age range of 31-35 years were 8 people, the age range of 36-40 years were 13 people, the age range of 41-45 years were 8 people, and in the range age $46-50$ years were 2 people. 


\section{c. Based on age of marriage}

Tabel 3. Data Categorization based on age of marriage (years)

\begin{tabular}{|c|c|c|}
\hline \multirow{2}{*}{ Age of marriage (years) } & \multicolumn{2}{|c|}{ Total Subjects } \\
\cline { 2 - 3 } & Working mothers & Not-working mothers \\
\hline $0-5$ & 6 & 1 \\
\hline $6-10$ & 16 & 13 \\
\hline $11-15$ & 4 & 16 \\
\hline $16-20$ & 5 & 4 \\
\hline $21-25$ & 0 & 0 \\
\hline $26-30$ & 1 & 0 \\
\hline Total & 32 & 32 \\
\hline
\end{tabular}

From the descriptive test carried out it is known that the number of working mothers with age of marriage 0-5 years were 6 people, age of marriage range between 6-10 years were 16 people, age of marriage with a span of 11-15 years were 4 people, age of married range of 16-20 years were 5 people, age of married range of 26-30 years amounted to 1 person, age of married range of 21-25 years were no people. While not-working mothers for age of marriage range of $0-5$ years was 1 person, age of marriage range of 610 years, amounting to 12 people, length of marriage with a range of 11-15 years were 15 people, age of marriage range of 16- 20 years were 4 people, age of marriage range of 21-25 years and range of 26-30 years amounted to none people.

Then to test the differences in gratitude of working mothers and notworking mothers are used independent t-test with significance or $\mathrm{p}=0.668, \mathrm{p}>$ 0.05 , then hypothesis was accepted. It means that there is no difference in gratitude among working mothers and not-working mothers. These results can also be obtained comparing $\mathrm{t}$-counts with t-tables ( $\mathrm{t}$-count $=1,983$ and $\mathrm{t}$-tables $=1,998$, $\mathrm{t}$-count $<\mathrm{t}$-table), which means that the hypothesis in this study was accepted. Thus it can be said in this study that gratitude does not differ significantly between working mothers and not-working mothers.

\section{DISCUSSION}

The results of this study indicate that there is no difference in gratitude between working mothers and not-working mothers $(p=0.668 ; p>0.05)$. The significance of the difference in gratitude between working mothers and notworking mothers can be seen from the comparison of t-counts with t-tables. The $\mathrm{t}$-count value of this study was 1,983 while the $\mathrm{t}$-table value was $1,998(\mathrm{t}$ - 
count <t-table), with a confidence level of $95 \%$. It means that hyphothesis is accepted, namely that there is no significant difference between working mothers and mother does not work.

In addition, to see the difference in gratitude for working mothers and not-working mothers can also be seen from the mean value of each group, where the mean for working mothers is 36.36 and the mean for non-working mothers is 34.34 . This shows that there is no significant difference in gratitude among working mothers and not-working mothers.

This is in accordance with the data categorization were obtained by researchers that in the moderate gratitude category of working mothers were 3 people $(9.4 \%)$, and gratitude of not-working mothers were 4 people $(12.5 \%)$. Whereas in the high gratitude category of working mother's were 29 people $(90.6 \%)$, and gratitude of working mothers were as many as 28 people $(87.5 \%)$. Thus it can be seen that gratitude for working mothers does not differ significantly from not-working mothers. Gratitude is not limited by the work they have, so there is no difference in gratitude that is owned by women who working at an organizational or not-working woman. This is in line with the research of Hefferon \& Boniwell, 2013 (in Kristianto, 2016). It is said that gratitude is a form of expression of happiness related to well-being. Grateful activities can maintain person's psychological well-being.In contrast to previous studies which found that there were differences in psychological well-being between working mothers and non-working mothers, in this study no significant differences in gratitude were found between working mothers and non-working mothers. This can be influenced by other factors that affect gratitude more.There are several factors affect gratitude. McCullough, Emmons \& Tsang (2004) states that there are 3 factors that contribute to one's gratitude: 1. Emotionality Well-being, is the tendency or extent to which a person reacts emotionally and feels satisfaction in his life, 2. Prosociality is one's tendency to be accepted by his social environment, 3. Spirituality is related to religion, faith that involves transcendental related vertical relationship with God. In line with Van Cappelen \& Rime (2014), which states that gratitude is also influenced by religiosity. One's understanding of religious values influences the extent to which a person is able to give thanks.It was also found that the highest number of respondents in this study were in the age range of 30-40 years, namely working mothers and mothers not working with the range of early adulthood into middle adulthood. Generally the respondents of this study are also in the span of marriage between 6-15 years. This shows that the two population groups, when viewed from demographic factors did not differ significantly, both working mothers and non-working mothers. Thus gratitude is not significantly influenced by demographic factors, including age 
and length of marriage.This study also has several weaknesses including the limited number of respondents (32 working mothers and 32 not-working mothers), so that the characteristics of the research respondents also cannot be distinguished significantly.

\section{RECOMMENDATIONS}

For working and not-working mothers (housewives), it is suggest that they will maintain or increase their gratitude by increasing spiritual (religious) aspects, prosociality (willingness to help and care for others), and increasing emotional well-being (feeling of well-being) emotionally). And for further researchers who are interested in examining the same variables as this study, it is recommended to examine other factors that can affect gratitude in working mothers and non-working mothers, especially spiritual factors (religiosity), emotional well-being and prosociality. Other demographic factors such as education, sex, race, marital status, individual personality traits, social status, occupation, background, culture, physical health, trust and emotions, positive self-esteem, and other external and internal factors in individuals can be considered also.

\section{REFERENCES}

Alteza, M. \& Hidayati, L. (2008). Work - Family Conflict Pada Wanita Bekerja: Studi Tentang Penyebab, Dampak dan Strategi Coping. Jurnal Universitas Negeri Yogyakarta.

APA. December 12, 2011. Working Moms Feel Better than Stay-at-Home Moms, Study Finds. Diakses tanggal 09 Oktober 2017. http://www.apa.org/news/press/releases/2011/12/working-moms.aspx.

Apsaryanthi, N.L.K, \& Lestari, M.D. (2017). Perbedaan tingkat Psychological Well - Being Pada Ibu rumah tangga dengan Ibu bekerja di Kabupaten Gianyar. Jurnal Psikologi Udayana, 2017, Vol. 4, No. 1, 110 - 118. Program Studi Psikologi, Fakultas Psikologi, Universitas Udayana. ISSN: 23545607110

Ciarrochi, J.W., Dy-Liacco, G.S. and Deneke, E. (2008). Gods or rituals? Relational faith, spiritual discontent, and religious practices as predictors of hope and optimism. Journal of Positive Psychology, 3(2): $120-26$ 
Emmons, R.A. \& Mccullough, M.E. (2004). The psychology of gratitude. New York : Oxford University Press.

Emmons, R.S \& Stern, R.(2013). Gratitude as a psychotherapeutic Intervention. Journal of Clinical Psychology: In Session, Vol. 69 (8), 846-855).

Jarden, A, Dr. (2011). Positive Psychological Assessment: A practical introduction to empirically validated research tools for measuring wellbeing. http://www.academia.edu

Kartono, K. 1981. Psychologi Wanita: Wanita sebagai Ibu dan Nenek. Bandung: Penerbit Alumni.

Kristanto, E. (2016). Perbedaan Tingkat Kebersyukuran pada Laki-laki dan Perempuan. Seminar Asean $2^{\text {nd }}$ Psychology \& Humanity. Psychology Forum UMM.

Lubis, N. L. (2013). Psikologi Kespro Wanita dan Perkembangan Reproduksinya. Jakarta: Kencana Prenada Media Group.

Ratnayanti, T.L. \& Wahyuningrum, E. (2016). Hubungan antara Gratitude dengan Psychological Well-Being Ibu yang memiliki Anak Tunagrahita di SLB Negeri Salatiga. Jurnal Satya Widya, Vol. 32, No. 2. Desember 2016: 57-64

Santrock, John W. 2002. Perkembangan Masa Hidup, Edisi 5, Jilid II. Terjemahan Life-Span Development. Jakarta: PT Gelora Aksara Pratama.

Sastriyani, S.H. 2005. Women in Public Sector (Perempuan di Sektor Publik). Yogyakarta: Pusat Studi Wanita UGM.

Seligman, M.E.P., Steen, T.A., Park, N., \& Peterson, C. (2005). Positive psychology progress: Empirical validation of interventions. American Psychologist.

Sigelman, Carol K and David R. Shaffer. 1994. Life -Span Human Development, Second Edition. Amerika: Brook Cole Publishing Company.

Snyder, C. R. \& Lopez, J. Shane. (2002). Handbook of Positive psychology. New York: Oxford University Press 